\title{
BATASAN TANGGUNG JAWAB DIREKSI ATAS KERUGIAN PERUSAHAAN
}

\author{
Oleh: \\ Trusto Subekti \\ Fakultas Hukum Universitas Jenderal Soedirman
}

\begin{abstract}
The effect of monetary crisis in year 1997 has caused many share companies in Indonesia close down because of unprofitable. At that moment, the price of shareholder drastic downwards, even exists to the zero level and effected to the bankruptcy. For the agenda of overcoming situation of share company, many ways have been conducted by the board of directories company to overcome the loss by using the law corridor, but somehow there are many party conduct action by impinged the laws. The problems which stated here is"how far a Board of directors can be responsible to the loss suffered of the company". From the theoretical study, it expected can be obtained the image of concerning indicator of a director that conduct the abuse of power.
\end{abstract}

Keywords: share company, board of directories, and abuse of power

\section{A. Pendahuluan}

Tanggung jawab dalam bahasa Inggrisnya adalah responsibility atau dalam bahasan Belanda adalah aansprekelijk, yang artinya adalah bertanggung jawab, terikat, bertanggung jawab menurut hukum atas kesalahan atau akibat suatu perbuatan. ${ }^{1}$ Ada pula istilah lainnya yang berkaitan adalah pertanggung jawaban yang dalam bahasa Inggris adalah accountability dan dalam bahasa Belanda adalah aansprakelijkheid yang artinya juga tanggung jawab, keterikan, tanggung jawab dalam hukum memikul tanggung jawab. ${ }^{2}$

Menurut Soehardi dikatakan bahwa dasar dari suatu tanggung jawab adalah suatu wewenang (authority) atau hak wewenang itu berkaitan dengan tugas dan merupakan kekuasaan yang melekat pada tugas atau pekerjaan (responsibility, duty), sedangkan hak melekat pada pribadi. Untuk melaksanakan suatu tugas akan tergantung pada capability atau ability yang berfungsi secara memadai untuk melaksanakan suatu tugas atau suatu tanggung jawab (responsibility). Hasil hubungan antara

\footnotetext{
Fockema Andrea, diterjemahkan oleh Adiwinata A. Teloeki dan H. Boerchanudin St. Batoeh, 1983, Kamus Istilah Hukum, Cet. Pertama, Jakarta: Binacipta, hlm 6.
}

2 Ibid, hal 6. responsibility dengan capability ini adalah suatu accountability atau suatu pertanggung jawaban. $^{3}$

Pada umumnya setiap orang harus bertanggung jawab atas segala tindakan atau perbuatannya. Pengertian orang ini termasuk pula suatu rechtspersoon. Orang dalam artian yuridis adalah setiap orang yang mempunyai wewenang hukum, yang artinya adalah kecapakan untuk menjadi subyek hukum, ${ }^{4}$ atau sebagai pendukung hak dan kewajiban, maka untuk itu terlebih dahulu harus ditentukan dulu status seseorang dalam suatu hubungan hukum.

Hubungan hukum mencerminkan adanya kepentingan-kepentingan dari pihak-pihak yang melakukan hubungan hukum, ada kehadiran hukum akan berfungsi untuk mengintegrasikan dan mengkoordinasikan kepentingan-kepentingan tersebut agar tidak saling bertubrukan (conflit of interest). Hukum melindungi kepentingan seseorang dengan cara mengalokasikan suatu kekuasaan kepadanya untuk bertindak dalam rangka kepentingannya tersebut. Kekuasaan yang diberikan oleh hukum itu disebut sebagai

\footnotetext{
3 Soehardi Sigit, 1992, Pengorganisasian, Yogyakarta: Fakultas Ekonomi Universitas Gadjah Mada, hlm. 25 -28.

4 Ali Chidir, 1987, Badan Hukum, Bandung: Penerbit Alumni, hlm. 7.
} 
hak. Antara hak dan kewajiban terdapat hubungan yang sangat erat, yang satu akan mencerminkan yang lain. Di satu sisi hak dan di sisi lainnya akan terlihat adanya kewajiban. ${ }^{5}$

\section{B. Tanggung Jawab Menurut Pasal 1365 KUHPerdata}

Pada Pasal 1365 KUHPerdata dikandung ajaran tentang tanggung jawab, seperti dalam rumusan sebagai berikut :

"Setiap orang bertanggung jawab tidak saja untuk kerugian yang disebabkan perbuatannya, tetapi juga untuk kerugian yang disebabkan kelalaian atau kurang hati-hatinya".

Pada Pasal 1367 KUHPerdata, ajaran mengenai tanggung jawab ini dikonkritkan lagi dengan diberikan rumusan sebagai berikut:

(1) Seorang tidak saja bertanggung jawab untuk kerugian yang disebabkan perbuatannya sendiri, tetapi juga untuk kerugian yang disebabkan perbuatan orang-orang yang menjadi tanggungannya atau disebabkan oleh-oleh barang-barang yang berada di bawah pengawasannya;

(2) Orang tua dan wali bertanggung jawab tentang kerugian yang disebabkan oleh anak-anak belum dewasa, yang tinggal pada mereka dan terhadap siapa mereka melakukan kekuasaan orang tua atau wali;

(3) Majikan-majikan dan mereka yang mengangkat orang-orang lain untuk mewakili urusanurusan mereka, adalah bertanggung jawab tentang kerugian yang ditertibkan oleh pelayan-pelayan atau bawahan-bawahan me-reka dalam melakukan pekerjaan untuk mana orang-orang ini dipakainya;

(4) Guru-guru sekolah dan kepala-kepala tukang bertanggung jawab tentang kerugian yang diterbitkan oleh murid-murid dan tukangtukang mereka selama waktu orang-orang ini berada di bawah pengawasan mereka;

(5) Tanggung jawab yang disebutkan di atas berakhir, jika orang tua-orang tua, waliwali, guru-guru sekolah dan kepala-kepala

5 Satijipto Rahardjo, 1996, Ilmu Hukum, Bandung: Penerbit Citra Aditya Bakti, hlm. 53. tukang itu membuktikan bahwa mereka tidak dapat mencegah perbuatan untuk mana mereka seharusnya bertanggung jawab itu.

Rumusan Pasal 1367 KUHPerdata di atas, menunjukan bahwa dalam KUHPerdata dikenal ada 2 (dua) jenis tanggung jawab, yaitu :

1) Tanggung jawab berdasarkan kesalahan, artinya seseorang dapat dimintai pertanggung jawaban atas kesalahan yang telah diperbuatnya dan akibat kesalahannya itu telah menimbulkan kerugian bago orang lain;

2) Tanggung jawab berdasarkan risiko, artinya seseorang dapat dimintai pertanggung jawaban atas kerugian yang diderita oleh orang lain bukan karena kesalahan yang bersangkutan, melainkan sebagai resiko yang ditanggungnya karena kesalahan orang lain dan orang tersebut adalah menjadi bawahannya atau menjadi tanggungnya, atau dalam pengawasannya.

Tanggung jawab karena kesalahan sebagaimana telah diatur dalam Pasal 1365 KUHPerdata dan Pasal 1367 KUHPerdata merupakan bentuk klasik pertanggung jawaban perdata.

\section{Tanggung jawab Direksi Perseroan}

\section{Wewenang (Authority)}

Wewenang Direksi suatu perseroan telah ditentukan dalam Undang-Undang Nomor 40 Tahun 2007 tentang Perseroan Terbatas dan rincian lebih lanjut atas wewenang tersebut dituangkan dalam Anggaran Dasar perseroan (Pasal 92 ayat (1) dan ayat (2) UU No. 40 Tahun 2007).

Seorang Direksi bertanggung jawab atas pengurusan perseroan untuk kepentingan dan tujuan perseroan (Pasal 92 UU No. 40 Tahun 2007). Atas dasar ketentuan tersebut maka seorang Direksi memiliki kekuasaan untuk melaksanakan tugas atau pekerjaan, dan di dalamnya terkandaung pula pihak-pihak yang melekat pada pribadi.

Wewenang atau kekuasaan yang dimiliki oleh seorang Direksi suatu perseroan didasarkan atas posisinya sebagai organ perseroan, artinya 
sebagai alat perlengkapan suatu perseroan (badan hukum). Dalam posisinya sebagai organ perseroan dalam bertindak dibatasi atas wewenang yang diberikan kepadanya selaku pihak mewakili perseroan (badan hukum). Seseorang yang menduduki posisi sebagai Direksi kemungkinan bertanggung jawab secara pribadi atas tindakan atau perbuatan yang dilakukan untuk perseroan yang diwakilinya. Hal ini bisa terjadi apabila ia melakukan suatu tindakan atau perbuatan yang tidak menjadi wewenangnya atau melampui batas wewenang yang dimilikinya.

Direksi dalam melaksanakan tugasnya harus mengacu pada ketentuan perundangundangan yang berlaku, Anggaran Dasar perseroan dan RUPS. RUPS adalah sebagai organ perseroan lainnya yang memiliki wewenang yang tidak diberikan kepada Direksi dan Komisaris, dalam batas yang ditentukan dalam Undang-undang dan atau Anggaran Dasar (Pasal 75 ayat (1) UU No. 40 Tahun 2007).

\section{Tugas (Responsibility)}

Tugas (Responsibility) adalah segala tindakan atau perbuatan dari seorang Direksi dalam manajemen, yang dilakukan untuk kepentingan dan atas nama perseroan (perusahaan). Tugas ini merupakan aspek dinamis dari status yang dimiliki seorang Direksi atau juga merupakan peranan (role) seorang Direksi dalam manajemen.

Direksi bertanggung jawab penuh dalam melaksanakan tugasnya untuk kepentingan perseroan dalam mencapai maksud dan tujuanya dan dengan berdasar atas itikad baik serta mengindahkan peraturan perundangudangan yang berlaku. Selaku Direksi melakukan tindakan atau perbuatan hukum atas prinsip perwakilan. Pelaksanaan tugas tersebut merupakan bentuk tanggung jawab yang dipikulnya sesuai wewenang yang dimiliki.

Tanggung jawab Direksi berkaitan dengan landasan wewenang yang dimiliki seorang Direksi Perseroan untuk bertindak untuk dan nama perusahaan. Direksi selaku manajer suatu perusahaan harus memperhatikan 2 (dua) hal, yaitu: selaku organ perusahaan dan sebagai seorang Direksi yang harus melaksanakan tugasnya secara profesional atas dasar prinsip fiduciary duty.

\section{Kemampuan (Capability)}

Tindakan atau perbuatan seorang Direksi dalam rangka pelaksanaan tanggung jawabnya dalam pengelolaan perusahaan dibutuhkan kemampuan (capability) agar tugas atau kewajiban dimaksud dapat tercapai sebaikbaiknya. Apabila seseorang memiliki kemampuan lebih besar dari tugas (responsibility) atau kewajibannya, maka cenderung akan mengunakan kemampuan lebih kecil dibandingkan tugas kewajibanya, maka cenderung tidak dapat melaksanakan tugas kewajibanya yang dilimpahkan kepadanya, sehingga akan melakukan tindakan atau perbuatan yang merugikan. ${ }^{6}$

Hubungan antara tugas kewajiban (responsibility) dengan kemampuan melaksnakan tugas kewajiban (capability) diatas apabila dihubungkan dengan pelaksanaan tugas Direksi dalam pengelolaan perusahaan, dapat dipergunakan untuk mengukur dapat tidaknya seorang Direksi Perusahaan dipertangung jawabkan atas tindakan atau perbuatan yang dilakukan untuk kepentingan perusahaannya.

\section{Pertanggung jawaban (Accountability)}

Suatu Accountability atau suatu pertanggung jawaban atas suatu tindakan seorang Direksi dapat dilihat dari apakah suatu tindakan atau perbuatan yang dilakukannya (responbility) berdasar atas wewenang (Authority), termasuk di dalamnya harus pula berdasar pada prinsip fiduciary duty, dan tindakan atau perbuatan (responbility) tersebut didukung oleh kadaan yang seimbang antara tugas kewajiban (duty atau responbility) dengan kemampuan melaksanakan tugas kewajiban (capability). Suatu tindakan hukum yang dilakukan seorang Direksi untuk dapat dipertanggung jawabannya (capability).

Menurut Moeljatno ${ }^{7}$ dikatakan adanya kemampuan bertanggung jawab harus ada:

\footnotetext{
Soehardi Sigit, 1992, Pengorganisasian, Yogyakarta: Fakultas Ekonomi UGM, hlm 29.

7 Moeljatno, 2000, Asas-Asas Hukum Pidana, Jakarta: Penerbit Rineka Cipta, hlm. 165.
} 
1) Kemampuan untuk membedabedakan antara perbuatan yang baik dan yang buruk, yang sesuai hukum dan melawan hukum;

2) Kemampuan untuk menentukan kehendaknya menurut keinsyafan tentang baik dan buruknya perbuatan tadi.

Apa yang dikemukakan oleh Moeljatno tersebut diatas sebetulnya dalam konteks pembicaraan kemampuan bertanggung jawab di aspek hukum perdata.

Dalam ini indikator kemampuan bertanggung jawab tersebut dapat dipergunakan dalam menilai suatu tindakan atau perbuatan seorang Direksi dapat tidaknya dipertanggung jawaban (Accountability) kepadanya. Indikator mengenai kemampuan bertanggung jawab dapat dikembangkan lebih lanjut dari pernyataan Moeljatno, yaitu yang pertama merupakan faktor akal (intelectual factor) yang dapat membeda-bedakan antara perbuatan yang diperbolehkan dan yang tidak. Yang kedua adalah faktor perasaan atau kehendak (volitional factor) yang dapat menyesuaikan tingkah lakunya dengan keinsyafan atas nama yang diperbolehkan dan mana yang tidak.

\section{Ruang Lingkup Tanggung Jawab Direksi Perusahaan}

Tanggung jawab Direksi dalam melakukan tindakan atau perbuatan hukum untuk dan atas nama perusahaan, dapat dijelaskan melalui posisi seorang Direksi terhadap perusahaan yang dipimpinya (organ PT) dan harus tunduk pula pada Anggaran Dasar Perusahaan, serta harus memperhatikan prinsip fiduciary duty, sebagai berikut :

\section{a. Selaku organ Perseroan}

Menurut Pasal 92 ayat (1) UU No. 40 Tahun 2007 tentang Perusahaan bahwa mengenai tanggung jawab Direksi disebutkan:

“Direksi menjalankan pengurusan Perseroan untuk kepentingan Perseroan dan sesuai dengan maksud dan tujuan Perseroan".

Melihat tanggung jawab dan posisi Direksi tersebut diatas menunjukan bahwa keberadaan Direksi dalam suatu perseroan merupakan keharusan karena sebagai "ar- tifical person" tidak dapat berbuat apa-apa tanpa adanya Direksi sebagai "natural person". Hubungan antara Perseroan dengan Direksi disini terlihat bukan sebagai hubungan atas dasar perjanjian kerja sebagaimana diatur dalam Pasal 1601 KUHPerdata dan juga tidak bisa diartikan seperti hubungan antara Majikan dengan buruh, seperti yang digambarkan oleh Imam Soepomo sebagai bekerja pada pihak lainnya berarti bekerja dibawah pimpinan pihak lain (Majikan) dan karena kewajiban buruh adalah melakukan pekerjaan menurut petunjuk dari Majikan. ${ }^{9}$

Hubungan antara Perseroan dengan Direksi lebih nampak pada hubungan perwakilan, yaitu Direksi mewakili perseroan dan dengan iktikad baik dan bertanggung jawab menjalankan tugas untuk kepentingan dan usaha perseroan (Pasal 92 ayat (1) UU No. 40 Tahun 2007). Pembatasan wewenang mewakili perseroan bagi Direksi diatur dalam Anggaran Dasar Perseroan (Pasal 92 ayat (2) UU No. 40 Tahun 2007).

Menurut Hartono Soerjopraktikno dikemukakan:

"Perwakilan dapat timbul dari perbuatan, yang sengaja bermaksud menimbulkan akibat itu (lastgeting machtiging)". ${ }^{10}$

Pemahaman mengenai perwakilan yang dikemukakan diatas apabila dicermati dapat dirinci menjadi:

1) Perwakilan yang berdasarkan kehendak atau lahir dari perjanjian;

2) Perjanjian yang berdasarkan karena bukan kehendak dalam arti yang lahir dari undang-undang.

Perwakilan dalam hubungan antara Perseroan dengan Direksi termasuk dalam pengertian perwakilan yang lahir bukan

8 I.G. Rai Widjaya, 2000, Hukum Perusahaan, Jakarta: Megapoin Divisi Dari Kesaint Blant, hlm. 208.

Imam Soeparno, 2001, Hukum Perburuhan bidang Hubungan Kerja, Penyunting Helena Poerwanto dan Suliati Rachmat, Cetakan kesembilan, Jakarta: Penerbit Djambatan, hlm. 92.

10 Soerjopraktino Hartono, 1994, Perwakilan Berdasarkan Kehendak, Edisi kedua, Yogyakarta: Penerbit PT. Mustika Wikasa, hlm. vi. 
karena perjanjian, melainkan lahir karena ketentuan undang-undang. Tugas seorang Direksi secara rinci telah dirumuskan dalam Anggaran Dasar, sehingga dalam bertindak atau berbuat dalam hukum seorang Direksi harus selalu menguji tindakannya pada Anggaran Dasar.

Dalam perwakilan mengenai siapa yang menurut hukum sebagai yang melakukan perbuatannya, dalam arti dilakukan oleh si wakil atau oleh orang yang diwakili, terdapat 3 (tiga) teori yang dijelaskan oleh Hartono Soerpraktiknyo, ${ }^{11}$ sebagai berikut:

(1) Teori representasi atau fiksi, bahwa si wakillah yang melakukan perbuatan. Dia tidak hanya berbuat /bertindak realiter, tetapi juga dialah yang yuridis menyatakan kehendaknya. Berdasarkan suatu fiksi maka akibat hukum dari perbuatannya tindakanya dipindahkan pada prinsipalnya;

(2) Teori organ (nuntius-theorie) yang melihat si wakil, person (pribadi) yang berbuat menurut hukum. $\mathrm{Si}$ wakil hanyalah organ yang tersedia untuk orang yang diwakili, yang kehendaknya untuk terjadinya hubungan hukum itu adalah menentukan;

(3) Teori koperasi, yang merupakan kombinasi dari teori reprensentasi dan teori organ perbuatan yang dilakukan oleh si wakil atas nama prinsipal terjadi karena sesungguhnya ada kerjasama yuridis antara wakil dan orang yang diwakili.

Pada dasarnya suatu perseroan apakah harus terikat pada tindakan atau perbuatan Direksi atau suatu Direksi harus bertanggung jawab secara pribadi atau tidak atas tindakan atau perbuatan yang dilakukannya, yang kemungkinan akan menimbulkan kerugian bagi pihak lain. Untuk ini dapat diperhatikan adanya 2 (dua) prinsip hukum yang berupa Doktrin "Ultra Virres" dan prinsip "Fiduciary Duty".

\section{b. Doktrin "Ultra Virres"}

Kewenangan Direksi ini harus dirujuk pada ketentuan yang berlaku sekarang, yaitu pada Pasal 97 ayat (1), ayat (2) dan ayat (3) UU No. 40 Tahun 2007 tentang Perseroan Terbatas, sebagai berikut:

(1) Direksi bertanggung jawab atas pengurusan Perseroan sebagaimana dimaksud dalam Pasal 92 ayat (1);

(2) Pengurusan sebagaimana dimaksud dalam ayat (1), wajib dilaksanakan setiap anggota Direksi dengan iktikad baik dan penuh tanggung jawab;

(3) Setiap anggota Direksi bertanggung jawab penuh secara pribadi atas kerugian Perseroan apabila yang bersangkutan bersalah atau lalai menjalankan tugasnya sesuai ketentuan sebagaimana dimaksud pada ayat (2).

Di negara-negara Anglo Saxon, dikenal suatu doktrin yang bersifat umum, dan agaknya doktrin inipun juga telah dimuat di dalam UU No. 40 Tahun 2007 tentang Perseroan Terbatas. Doktrin tersebut dikenal dengan sebutan "Ultra Virres doctrine", yaitu:

"The trem Ultra Virres "beyond the powers" in corporate law acts of corporation that are beyond the authority given to it under its charter of under the statutes by wich it was incorporateed are ultra virres acts. In other words, acts in furtherance of the corporation's expresed purposesed are whithin the corporate power, acts beyond the scope of corporate business as described in the charter are ultra virres acts thus; ultra virres acts can be understood only withtin the contexs of the particular stated purpose for which the corporation was organized". ${ }^{12}$

Istilah ultra virres berarti diluar kewenangan di hukum perseroan, tindakan corporasi melampui kewenangan yang diberikan kepadanya oleh anggaran dasar disebut tindakan ultra virres, dengan per-

12 Kenenth Clakson W. Roger Miller Gaylord A. Jens, Franks B. Creas, 1991, West's Businees Law, Fith Edisition West Publising Company, St. Paul New York, Los Angeles, San Fransisco, Page 782. 
kataan lain suatu tindakan untuk melaksanakan tujuan perseroan yang secara tegas disebutkan berada di dalam ruang lingkup kewenangan. Tindakan yang diluar ruang lingkup kewenangan bisnis perseroan sebagaimana disebutkan pada akta pendirian berarti tindakan ultra virres, jadi tindakan ultra virres hanya dapat dimengerti di dalam konteks tujuan perseroan untuk mana perseroan itu dibentuk.

Kewenangan Direksi sebagaimana yang digambarkan pada doktrin ultra virres menunjukan bahwa kewenangan Direksi telah ditentukan baik di dalam Anggaran Dasar maupun disebutkan dalam peraturan perundang-undangan yang berlaku (UU No. 40 Tahun 2007). Pengaturan mengenai kewenangan Direksi tersebut tidaklah mungkin bisa dirinci secara pasti, artinya ada hal-hal yang bisa secara tegas disebutkan, dan ada hal-hal yang tidak secara tegas disebutkan dalam kewenangan Direksi.

\section{c. Prinsip fiduciary duty}

Sebelum mempertimbangkan aspek hubungan perwakilan dan ultra virres doctrine tersebut diatas, dalam tanggung jawab Direksi harus pula mempertimbangkan prinsip fiduciary duty. Berdasarkan prinsip ini mestinya Direksi memiliki kebebasan dalam menjalankan tugas dan kewenangannya sepanjang tidak melanggar ketentuan UndangUndang dan Anggaran Dasar, dalam hal ini pemegang saham mayoritas tidak boleh mempengaruhi apalagi memaksakan kehendak kepada Direksi dalam pengelolaan perseroan selain melalui mekanisme RUPS. ${ }^{13}$ Adanya prinsip fiduciary duty ini diharapkan agar Direksi dalam mengelola perseroan dapat lebih profesional apalagi seorang Direksi dituntut agar memiliki managerial skill yang cukup baik.

Prinsip fiduciary duty ini berlaku bagi Direksi dalam menjalankan tugasnya baik dalam menjalankan fungsinya sebagai manajemen, yaitu dalm mimpim perusahaan,

13 Hariyanto, 2001. Pertangunggjawaban Direksi PT Dalam Sistem Hukum Perseroan Indonesia, Majalah Mimbar Hukum, Yogyakarta: Fakultas Hukum UGM, hlm. 44. maupun sebagai representasi, yaitu mewakili perseroan di dalam dan di luar pengadilan. ${ }^{14}$ Selanjutnya seorang Direksi perseroan haruslah mempunyai kepedulian dan kemampuan (duty of care and skill), iktikad baik, loyalitas dan kejujuran terhadap perseroan dengan "derajat yang tinggi" (high degree).

Mengenai duty of care yang merupakan prinsip yang harus dipegang oleh seorang Direksi, oleh Munir Fuady juga dirumuskan prinsip-prinsip hukum yang harus diperhatikan :

1) Standar kepedulian seorang Direksi (standard of care), yang terinci sebagai berikut:

a. Selalu beriktikad baik;

b. Tugas-tugas dilakukan kepedulianya seperti yang dilakukan oleh biasa yang berhati-hati (ordinarily prudent person) dalam posisi dan situasi yang sama, atau seperti yang dilakukan oleh orang tersebut untuk kepentingan bisnis pribadinya;

c. Tugas-tugas dilakukan dengan cara yang dipercayanya secara logis (reasonnably believe) merupakan kepentingan yang terbaik (best interest) dari perseroan.

2) Secara hukum, seorang Direksi perseroan tidak akan bertanggung jawab sematamata atas salah dalam mengambil keputusan (mere errors). Bahkan, asalkan dia beriktikad baik dan cukup berhatihati, keputusan yang salah tidak dapat dibebankan kepada Direksi, sungguhpun kesalahan tersebut akibat kurang pengalaman atau kurang komprehensif dalam mengambil keputusan. Dengan demikian, suatu hoinest mistake yang dilakukan oleh Direksi masih dapat ditoleransi oleh hukum. Bahkan Hakim tidak diperkenalkan untuk melakukan penilaian bisnis yang berbentuk second guess terhadap keputusan Direksi. Ini sesuai pula dengan prinsip-prinsip hukum yang

\footnotetext{
14 Munir Fuady, 2002, Doktrin-Doktrin Modern Dalam Corporation Law dan Eksistensinya Dalam Hukum Indonesia, Bandung: Penerbit PT. Aditya Bakti, hlm. 32.
} 
terdapat dalam "teori keputusan bisnis" (business judgement rule);

3) Secara hukum, seorang Direktur tidak diharapkan tingkat keahlian (degree skill) kecuali hanya setingkat yang dapat diharapkan secara wajar dari orang yang sama pengetahuan dan sama pengalaman dengannya, atau yang dalam bahasa hukum popular dengan istilah degree of skill that reasonably be expected from a person of this knowledge and experience;

4) Terhadap tugas-tugas Direksi yang dapat didelegasikan kepada bawahanya, maka berlaku asumsi hukum bahwa pihak bawahan telah melakukan tugasnya secara jujur (kecuali ada kerugian sebaliknya);

5) Direksi akan bertanggung jawab secara hukum manakala dia gagal dalam mengarahkan (failure to direct) bawahannya dan jalannya perusahaan;

6) Direksi akan bertanggung jawab secara hukum manakala di mengetahui, membantu atau ikut melakukan tindakan yang bertentangan dengan hukum, sungguhpun hal tersebut semata-mata untuk kepentingan perseroan yang dipimpinnya.

Dalam tugas mempedulikan (duty of care) yang diharapkan oleh seseorang Direktur perusahaan, diharapkan harus dilakukan secara hati-hati sehingga tidak terjadi adanya perbuatan atau tindakan yang merugikan pihak lain karena kelalaiannya (onrechmatige daad). Untuk itu dalam tindakan atau perbuatannya seorang Direktur harus memenuhi 2 (dua) syarat : ${ }^{15}$

a. Syarat prosedural, yang artinya Direksi harus selalu sungguh-sungguh memperhatikan jalannya perseroan;

b. Syarat subtantif, yang artinya bahwa dalam mengambil keputusan perseroan harus didasarkan atas pertimbangan yang rasional. Sebagai standar rasional disini diukur dari keputusan tersebut terlihat sebagai respon yang wajar terhadap situasi yang ada, atau sebagai suatu

15 Ibid, hlm. 49-50. diskresi yang dibenarkan oleh hukum, atau bukan suatu diskresi yang melanggar hukum.

Keadaan yang meliputi seorang Direksi suatu perusahaan adalah sangat kompleks, sebab satu pihak ia bertindak untuk dan atas nama serta untuk kepentingan perusahaan dan harus bertanggung jawab penuh atas pengurusan perusahaan, dan ia juga harus bertindak profesional dalam menjalankan perusahaan yang dipimpinnya. Dipihak lain ada kemungkinan ia menghadapi masalah yang mempengaruhi kebijakannya. Perlu diingat kembali bahwa masalah perusahaan adalah masalah yang berpangkal pada perilaku bisnis, sehingga nuansa bisnis yang penuh dengan aspek persaingan dan permainan serta trik-trik dalam bisnis adalah sangat berpengaruh.

Kebebasan yang dimiliki seorang Direksi dalam memimpin suatu perusahaan (fungsi manajemen) ini sering kali masih terlihat dapat dipengaruhi oleh pemegang saham mayoritas. Pengaruh pemegang saham mayoritas ini akan semakin terlihat apabila dikaitkan dengan adanya Perusahaan Kelompok (Group Company) atau yang dikenal sebagai konsern.

Menurut Raaijimakers ${ }^{16}$ suatu Konsern atau Perusahaan Kelompok adalah suatu susunan dari perusahaan-perusahaan yang secara yuridis tetap mandiri dan yang satu dengan lain merupakan satu kesatuan ekonomi yang dipimpin oleh suatu perusahaan induk.

Dalam Perusahaan Kelompok si induk perusahaan dapat mengendalikan perusahaan-perusahaan lain yang tergabung dalam kelompoknya, walau secara yuridis di antara perusahaan-perusahaan tersebut tidak terkait satu sama lain. Cara membentuk Konsern bisda dilakukan dengan membuat perusahaan anak. Dengan demikian bisa terjadi seorang Direksi menjadi dapat dipengaruhi atau dikendalikan oleh perusahaan

\footnotetext{
16 Emny Pangaribuan Simanjuntak, 1994, Perusahaan Kelompok (Group Company), Yogyakarta: Seksi Hukum Dagang Fak. Hukum UGM, hlm. 1.
} 
induknya. Oleh karena itu tanggung jawab Direksi atas tindakan yang dilakukannya ada kemungkinan akan berkait dengan perusahaan lain (induk), apabila dapat diketahui bahwa tindakan Direksi yang kemungkinan menimbulkan kerugian bagi pihak lain adalah sebagai akibat perbuatan perusahaan induk.

\section{E. Penutup}

Menyimak pendekatan teori yang dipaparkan tugasnya sebagai pengurus perseroan memiliki wewenang yang ditentukan dan dibatasi oleh :

1. Ketentuan Undang-undang (UU No. 40 Tahun 2007 dan UU lainnya yang terkait);

2. Anggaran Dasar Perseroan;

3. RUPS (Rapat Umum Pemegang Saham);

4. Doktrin "Ultra Virres";

5. Prinsip Fiduciary Duty.

Apabila seorang Direksi melakukan tindakan diluar ketentuan dan batasan-batasan diatas, berarti telah keluar dari prinsip hukum perwakilan dan dikualifikasi telah melakukan tindakan penyalahgunaan wewenang sebagai indikatornya adalah :

1. Bertindak diluar wewenang yang diberikan dan tidak mengikuti mekanisme yang telah ditentukan dalam Anggaran Dasar Perusahaan;

2. Melakukan tindakan melawan hukum baik dalam kualifikasi perbuatan melawan hukum perdata maupun pidana.

\section{Daftar Pustaka}

Ali, Chidir. 1987. Badan Hukum, Bandung: Penerbit Alumni;
Andrea, Fockema. 1983. Kamus Istilah Hukum (diterjemahkan oleh Adiwinata A. Teloeki dan H. Boerchanudin St. Batoeh), Cetakan Pertama. Jakarta: Binacipta;

Clakson, Kenenth. W. Roger Miller Gaylord A. Jens, Franks B. Creas. 1991. West's Businees Law, Fith Edition: St. Paul New York, Los Angeles, San Fransisco: West Publising Company;

Fuady, Munir. 2002. Doktrin-Doktrin Modern Dalam Corporation Law dan Eksistensinya Dalam Hukum Indonesia. Bandung: Penerbit PT. Aditya Bakti;

Hariyanto. 2001. Pertangunggjawaban Direksi PT Dalam Sistem Hukum Perseroan Indonesia. Yogyakarta: Mimbar Hukum Majalah, Fakultas Hukum UGM;

Moeljatno. 2000. Asas-Asas Hukum Pidana. Jakarta: Penerbit Rineka Cipta;

Rahardjo, Satijipto. 1996. Ilmu Hukum. Bandung: Penerbit Citra Aditya Bakti;

Soehardi, Sigit. 1992. Pengorganisasian. Yogyakarta: Fakultas Ekonomi Universitas Gadjah Mada;

Soerjopraktino, Hartono. 1994. Perwakilan Berdasarkan Kehendak. Edisi ke dua. Yogyakarta: Penerbit PT. Mustika Wikasa;

Soeparno, Imam. 2001. Hukum Perburuhan bidang Hubungan Kerja. Penyunting Helena Poerwanto dan Suliati Rachmat, Cetakan kesembilan, Jakarta: Penerbit Djambatan;

Simanjuntak, Emny Pangaribuan. 1994. Perusahaan Kelompok (Group Company). Yogyakarta: Seksi Hukum Dagang Fak. Hukum UGM;

Widjaya, I.G. Rai. 2000. Hukum Perusahaan, Jakarta: Megapoin Divisi Dari Kesaint Blant; 